\title{
Thyroid autoimmunity in Type 2 (non-insulin-dependent) diabetic patients of Caucasoid, Black and Mexican origin
}

\author{
S. Kasim and A. Bessman \\ Rancho Los Amigos Hospital, University of Southern California School of Medicine, Downey, California, USA
}

\begin{abstract}
Summary. Four hundred and forty-nine patients with Type 2 (non-insulin-dependent) diabetes mellitus and 270 control subjects from Caucasoid, Mexican and black origins were screened for the presence of thyroid microsomal antibodies. Mexican female control subjects had a significantly higher frequency of thyroid microsomal antibodies when compared with black female controls $(21 \%$ versus $6 \%, p<0.01)$. Type 2 diabetic patients did not have a higher frequency of thyroid microsomal antibodies when compared with their sex- and race-matched control counterparts. The subgroup of diabetic
\end{abstract}

patients who required insulin for the control of their blood glucose did not have a higher frequency of thyroid microsomal antibodies when compared with non-insulin-requiring diabetic patients. In conclusion autoimmunity against thyroid gland, as manifested by thyroid microsomal antibodies, is not more common in Type 2 diabetic patients when compared with sex- and race-matched control subjects.

Key words: Type 2 diabetes, thyroid microsomal antibodies, race.
Information regarding the relationship between Type 2 diabetes and autoimmunity is very limited. A previous study which determined thyroid microsomal antibody (TMA) status in Mexican American patients with Type 2 diabetes reported a $2.8 \%$ prevalence [1]. Other studies reported $9.2 \%$ and $9.1 \%$ frequencies of thyroid antibodies in Type 2 diabetes, which were similar to the frequency seen in control subjects. In these reports the majority of the patients were Caucasoid but the distribution of TMA according to sex was not specified $[2,3]$. The frequency of thyroid antibodies in black Type 2 diabetic patients is unknown.

A subgroup of patients with Type 2 diabetes require insulin for control of their blood glucose levels. The rôle of autoimmunity in insulin-requiring versus non-insulin-requiring diabetic groups may be different. The frequency of autoantibodies in these subgroups of Type 2 diabetic subjects is also not known. Even for normal subjects there is no available study comparing the frequency of thyroid antibodies in the different races and sexes of the same population.

In this study we determined the frequency of TMA in male and female normal subjects and insulin-requiring and non-insulin-requiring Type 2 diabetic patients of Caucasoid, black and Mexican origin.

\section{Subjects and methods}

\begin{abstract}
Subjects
Rancho Los Amigos Hospital is a Los Angeles County facility which provides health care for medically indigent patients. Two hundred and seventy normal subjects who attended Rancho Los Amigos Hospital Employee Health Service for their pre-employment physical examinations participated in the study. Four hundred and forty-nine diabetic patients who regularly attended the diabetic outpatient clinics for at least 6 months before the study were also recruited after a medical history was taken and a physical examination was carried out. Insulin-treated patients were carefully questioned about the mode of onset of diabetes and previous ketoacidotic episodes. Those patients who had medical histories compatible with Type 1 (insulindependent) diabetes were excluded from the study. The majority of non-insulin-requiring patients were treated with diet and oral hypoglycaemic agents. The number of patients who were treated with diet alone ranged between two to eight in each subgroup. Patients with previously diagnosed thyroid disease were excluded since the objective of the study was to determine the previously undetected thyroid pathology in diabetic patients. Patients with co-existent autoimmune disease, such as rheumatoid arthritis, systemic lupus erythamatosus, etc., were also excluded. A portion of sera obtained for other required testing was utilized for this study after obtaining verbal consent.
\end{abstract}

\section{Thyroid microsomal and thyroglobulin antibody testing}

The antibodies were measured by the red cell haemagglutination method $[4,5]$. A positive reading was defined as the presence of either 
Table 1. Age distribution of the subjects studied

\begin{tabular}{|c|c|c|c|c|c|c|}
\hline & \multicolumn{6}{|c|}{ Age (years) } \\
\hline & \multicolumn{2}{|c|}{ Caucasoid subjects } & \multicolumn{2}{|c|}{ Black subjects } & \multicolumn{2}{|c|}{ Mexican subjects } \\
\hline & Female & Male & Female & Male & Female & Male \\
\hline Control subjects & $\begin{array}{l}36 \pm 11 \\
(n=50)\end{array}$ & $\begin{array}{l}34 \pm 9 \\
(n=50)\end{array}$ & $\begin{array}{l}30 \pm 9 \\
(n=50)\end{array}$ & $\begin{array}{l}37 \pm 12 \\
(n=50)\end{array}$ & $\begin{array}{l}39 \pm 13 \\
(n=43)\end{array}$ & $\begin{array}{l}34 \pm 11 \\
(n=27)\end{array}$ \\
\hline Insulin-requiring patients & $\begin{array}{l}60 \pm 12 \\
(n=51)\end{array}$ & $\begin{array}{l}54 \pm 18 \\
(n=64)\end{array}$ & $\begin{array}{l}64 \pm 14 \\
(n=59)\end{array}$ & $\begin{array}{l}62 \pm 15 \\
(n=36)\end{array}$ & $\begin{array}{l}62 \pm 13 \\
(n=39)\end{array}$ & $\begin{array}{l}61 \pm 11 \\
(n=51)\end{array}$ \\
\hline
\end{tabular}

Results are expressed as mean \pm SD. $n=$ number of subjects studied in each group

Table 2. Prevalence of thyroid microsomal antibodies among control subjects and insulin-requiring and non-insulin-requiring Type 2 diabetic patients

\begin{tabular}{|c|c|c|c|c|c|c|c|c|c|c|c|c|}
\hline \multirow[t]{2}{*}{ Patient groups } & \multicolumn{4}{|c|}{ Caucasoid subjects } & \multicolumn{4}{|c|}{ Black subjects } & \multicolumn{4}{|c|}{ Mexican subjects } \\
\hline & No. & $\%$ & No. & $\%$ & No. & $\%$ & No. & $\%$ & No. & $\%$ & No. & $\%$ \\
\hline Control subjects & 8 out of 50 & 16 & 5 out of 50 & 10 & 3 out of 50 & 6 & 3 out of 50 & 6 & 9 out of $43^{a}$ & 21 & 2 out of 27 & 7 \\
\hline $\begin{array}{l}\text { All diabetic } \\
\text { patients }\end{array}$ & 26 out of 93 & 28 & 15 out of 91 & 17 & 7 out of 82 & 9 & 2 out of 49 & 4 & 11 out of 60 & 18 & 7 out of 74 & 10 \\
\hline $\begin{array}{l}\text { Non-insulin- } \\
\text { requiring patients }\end{array}$ & 9 out of 42 & 21 & 3 out of 27 & 11 & 2 out of 23 & 9 & 1 out of 13 & 8 & 5 out of 21 & 24 & 2 out of 23 & 9 \\
\hline
\end{tabular}

${ }^{a} p<0.01$ when compared to black female control subjects

antibody at a titre of $1 / 100$ or more diluted serum sample. Statistical analyses were performed using the $\chi^{2}$ test.

\section{Results}

\section{The relative frequencies of thyroid microsomal and thyroglobulin antibodies}

The sera obtained from the first 140 subjects were tested for both antibodies. Twenty-nine subjects had anti-microsomal antibodies. Among those, 13 (45\%) also had thyroglobulin antibodies. In one subject the thyroglobulin antibody titre was higher than the microsomal antibody titre $(1 / 320$ and $1 / 160$, respectively). There was no serum sample which was positive for thyroglobulin antibody but not for microsomal antibody. For the rest of the study subjects, thyroglobulin antibody was tested only if the microsomal antibody was positive in the serum sample. Twenty-nine percent of these samples were also positive for thyroglobulin antibodies. Titres of each antibody ranged between $1 / 160$ to $1 / 10240$. Since the number of subjects who had both antibodies was small in each subgroup, the results are not reported separately.

\section{Control subjects}

The age distribution of the study subjects is shown in Table 1 and the frequencies of thyroid microsomal antibodies are summarized in Table 2 . When the differences between sexes in the same race and the differences among the races in the same sex were compared, the only significant difference was between the Mexican and black females: the prevalence of TMA was $21 \%$ in Mexican and $6 \%$ in black females $(p<0.01)$. However, Mexican female control subjects were significantly older than black female controls. When the data were re-analyzed to compare a randomly selected agematched subgroup of black female controls with Mexican female control subjects, the difference still remained significant $(p<0.025)$.

\section{Patients with Type 2 diabetes}

The diabetic patients were significantly older than their sex- and race-matched control counterparts. When the prevalence of the antibodies in the diabetic subjects were compared to the sex- and race-matched control subjects the differences were not significant. 


\section{Insulin-requiring versus non-insulin-requiring diabetic patients}

Insulin-requiring patients were usually treated with a single injection of intermediate acting insulin alone or in combination with a short-acting insulin. The patients were free of ketonuria. The prevalence of TMA was not significantly greater in insulin-requiring patients when compared with the sex- and race-matched non-insulinrequiring diabetic or control subjects.

\section{Discussion}

The frequency of thyroid antibodies has been reported as $2 \%-20 \%$ in the general population [6-8]. The prevalence of TMA is generally lower among Caucasoid males $(3 \%-10 \%)$ than Caucasoid females $(12 \%-20 \%)$. We are not aware of any reports of the frequency of TMA among Mexican and black control subjects of the different sexes. Our study indicates that the lower frequency of TMA found among black diabetic subjects is also observed in the black control population; this agrees with the concept that black subjects are less susceptible to organ-specific autoimmunity [9]. The prevalence of TMA among Type 2 diabetic patients was not significantly higher than in their non-diabetic counterparts. Riley et al. reported that the frequency of TMA shows a major increase after the fifth decade of life [10]. The diabetic patients in this study were significantly older than the control subjects; despite that, they did not have a significantly higher frequency of TMA.

Previous studies indicate that Type 2 diabetic patients with positive islet cell antibodies are likely to develop insulin deficiency and require insulin [11]. In our study we searched for a possible relationship between TMA and requirements for insulin for the control of blood glucose. Caucasoid insulin-requiring diabetic patients, both male and female, tended to have a higher frequency of TMA than non-insulin-requiring diabetic patients and Caucasoid control subjects but these differences were not significant.

In conclusion, Type 2 diabetic patients did not have a higher frequency of TMA when compared with their race- and sex-matched control counterparts. There was no relationship between TMA and the mode of treatment required for the control of blood glucose.

Acknowledgements. We would like to thank Ms. W. Talbott for referral of the control subjects, Ms. V. Boren for typing the manuscript, and Ms. H.Ostegaard for technical assistance.

\section{References}

1. Zeidler A, Frasier DS, Penny R, Stein RB, Nicoloff JT (1982) Pancreatic islet cell and thyroid antibodies, and islet cell function in diabetic patients of Mexican American origin. J Clin Endocrinol Metab 54: 949-954

2. Fialkow PJ, Zavala C, Nielson R (1975) Thyroid autoimmunity: increased frequency in relatives of insulin-dependent diabetes patients. Ann Int Med 83 (2): 170-175

3. Gray RS, Irvine WJ, Taft AD, Seth J, Cameron HD, Clarke BF (1979) Unrecognized thyroid failure in diabetes mellitus. J Clin Lab Immunol 2: 221-224

4. Witebsky E, Rose NE, Terpeon K (1957) Chronic thyroiditis and autoimmunization. JAMA 164: 1439-1447

5. Witebsky E, Rose NR, Paine GR (1957) Thyroid specific antibodies. Ann NY Acad Sci 69: 669-677

6. Basteine PA, Van Haelst L, Goldstein J (1977) Asymptomatic autoimmune thyroiditis and coronary heart disease. Lancet 2: 155-158

7. Basteine PA, Neve P, Bonnynns M (1971) Preclinical hypothyroidism: a risk factor for coronary heart disease. Lancet 1: 203-205

8. Tanner AR, Scott-Morgan L, Mardell R, Lloyd RS (1982) The incidence of occult thyroid disease associated with thyroid antibodies identified on routine antibody screening. Acta Endocrinol (Copenh) 100:31-35

9. Neufeld M, Maclaren NK, Riley WJ, Lezotte D, McLaughlin JV, Silverstein J, Rosenbloom AL (1980) Islet cell and other organspecific antibodies in US Caucasians and blacks with insulin-dependent diabetes mellitus. Diabetes 29: 589-592

10. Riley WJ, Winer A, Goldstein D (1983) Coincident presence of thyrogastric autoimmunity at onset of Type 1 (insulin-dependent) diabetes. Diabetologia 24: 418-421

11. Reaven GM (1980) Autoimmunity and diabetes mellitus. In: Podolsky's clinical diabetes: modern management. AppletonCentury Crofts, New York, pp 30-33

Received: 26 October 1983

and in revised form: 13 March 1984

Dr. Sidika Kasim

Diabetes Service, Rm. $256 \mathrm{HB}$

Rancho Los Amigos Hospital

7601 E. Imperial Highway

Downey, California 90242

USA 